\title{
Clinical Profile and Underlying Cause of Acute Pancreatitis among a Group of Bangladeshi Patients
}

\author{
A N M. Saifullah*1, Madhu Sudan Saha², Bimal Chandra Shil ${ }^{3}$, \\ Ali Monsur Md. Shariful Islam ${ }^{4}$ Arifa Akhter ${ }^{5}$, Md. Mamun-ur Rashid ${ }^{6}$
}

\section{Abstract}

Introduction:Acute Pancreatitis is a medical emergency, which is one of the most common conditions for hospital admission. Very few studies have yet investigated in Bangladesh. Objective of this study was to define demographic characteristics, clinical profile \& underlying etiologies. Materials and Methods: This hospital based cross sectional descriptive study was performed in Sir Salimullah Medical College Mitford Hospital, Dhaka \& North East Medical College, Sylhet, Bangladesh from January 2015 to December 2017. One hundred and five consecutive patients of acute pancreatitis (AP) were enrolled for this study. Clinical features and investigations were systematically recorded. Diagnosis of acute pancreatitis was made by the presence of the two of the three following criteria: $i$. abdominal pain consistent with the disease ii. serum amylase and /or lipase greater than three times from the upper limit of normal, and/or iii. characteristic findings of abdominal imaging. Results: Total of 105 patients took part in the study, of them 65 were male. The mean age was $42.76 \pm 15.88$. Abdominal pain \& vomiting was the most common mode of presentation. Gall stone and hypertriglyceridaemia were responsible of $20 \%$ of acute pancreatitis. Ascariasis also causes acute pancreatitis in two patients. Conclusion: Acute pancreatitis is a condition associated with high morbidity and mortality. Ascariasis also causes acute pancreatitis in endemic area. Patients usually respond conservative treatment but endoscopic treatment is effective in few cases. Surgery is rarely required.

Keywords: Pancreatitis, Gallstone, Serum lipase.

Number of Tables: 03; Number of References: 13; Number of Correspondence: 07.

*1. Corresponding Author:

Dr. A N M. Saifullah

Assistant Professor

Department of Gastroenterology

Sir Salimullah Medical College \& Mitford Hospital.

E-mail: saifullahanm@gmail.com.

Mobile:01915055273

2. Prof. Dr. Madhu Sudan Saha

Professor

Department of Gastroenterology

North East Medical College, Sylhet.

3. Dr. Bimal Chandra Shil

Associate Professor \& Head

Department of Gastroenterology

Sir Salimullah Medical College \& Mitford Hospital.

4. Dr. Ali Monsur Md. Shariful Islam

Associate Professor

Department of Gastroenterology

Rangpur Medical College, Rangpur.

5. Dr. Arifa Akhter

Assistant Professor

Bashundhora Ad-din Medical College

Keranigonj, Dhaka, Bangladesh.

6. Dr. Md. Mamun-ur Rashid, MD (Phase B)

Gastroenterology, Resident

Department of Gastroenterology

Sir Salimullah Medical College \& Mitford Hospital.

\section{Introduction:}

Acute Pancreatitis is a potentially serious condition with an overall mortality of $10 \%$. But more than $80 \%$ cases are mild \& have a good outcome $^{1}$. The incidence rate of acute pancreatitis seems to be increasing without any changes in case fatality $\mathrm{rates}^{2}$. The population is increasingly over weight. So the incidence of gallstones is also rising in our society. This is the most common cause of acute pancreatitis $^{3}$.

Early diagnosis is important for its management. Symptoms of acute pancreatitis vary considerably. So clinician must carefully evaluate the patient with history, physical examination, laboratory tests \& imaging studies before arriving a correct diagnosis. If the cause of the attack can be eliminated there will be no further attack and the pancreas will return to normal in terms of its morphology and function ${ }^{4}$. Mortality associated with acute pancreatitis has decreased overtime. Death is more likely in certain subgroups of patients including elderly, co-morbidity, severe coexisting hospital acquired infection \& organ dysfunction ${ }^{5}$.

The main objective of this study was to observe the clinical presentation, underlying cause and outcome among hospital admitted patients in acute pancreatitis.

\section{Materials \& Methods:}

This cross sectional descriptive study was carried out in the Department of Gastroenterology, Sir Salimullah Medical College Mitford Hospital, Dhaka \& North East Medical College, Sylhet, Bangladesh from January 2015 to December 2017. Patients attending at indoor \& outpatient department of gastroenterology with acute pancreatitis were the study population. Informed written consent was taken from the patient or guardian before the study. Data were 
recorded in a predesigned form.

Inclusion criteria were: Patients with age 18 years or more diagnosed as acute pancreatitis were included in this study.

Exclusion criteria were: Patient with chronic pancreatitis \& pancreatic malignancy, patient having liver disease, pulmonary or cardiac disease or other serious co morbid condition were excluded from this study. Diagnosis of acute pancreatitis was made by the presence of the two of the three following criteria: i. abdominal pain consistent with the disease ii. serum amylase and/or lipase greater than three times from the upper limit of normal, and/or iii.characteristic findings of abdominal imaging ${ }^{6}$. Patients were classified as mild, moderate \& severe acute pancreatitis based on Atlanta Revision Criteria (2013). Complete blood count, liver function test, renal function test, serum amylase, serum lipase, fasting blood sugar, lipid profile, serum calcium, CRP, chest X-ray \& ultrasonography of whole abdomen were done in all patients. Computed tomography (CT) of abdomen was done when indicated \& CT severity index was calculated. Severe acute pancreatitis was defined as patients having persistent two or more organ failure for more than 48 hours e.g. Systolic blood pressure $\leq 90 \mathrm{~mm} \mathrm{Hg}$ or $\mathrm{PaO} 2 \leq$ $60 \%$, renal failure (S.creatinine $\geq 2 \mathrm{mg} / \mathrm{dl}$ after rehydration) $\&$ gastrointestinal bleeding $>500 \mathrm{ml}$ of blood loss $/ 24 \mathrm{hrs}$. Patients with severe acute pancreatitis were managed in ICU. Mild \& moderate acute pancreatitis managed in ward. Surgery was done in patients who did not improve on intensive medical management.

All data were collected and analyzed by SPSS-22. p value $<0.05$ was accepted as significant. The summarized data were interpreted accordingly and was then presented in the form of tables. Categorical data were tested with Chi-square test and continuous data were tested with unpaired t-test.

\section{Results:}

A total of 105 acute pancreatitis patients were enrolled in this study. Of the 105 cases, 65(61.9\%) were male. Age of the patient ranged from 21-60 years. Incidence of acute pancreatitis below 50 years was significantly higher $(\mathrm{p}<0.01)$. Among them $58(55.2 \%)$ hailing from rural area in our study \& most were belongs to lower middle socioeconomic condition 55(52.4\%). Detail demographic, clinical profile of study population is shown in Table-I. The most common presentation were upper abdominal pain $(100 \%) \&$ vomiting (77\%). Among the patient $63(60 \%)$ patient was suffering from fever. Ascites \& pleural effusion were present in $04(3.8 \%) \& 03(3 \%)$ respectively. Ascites disappeared in patient before discharge from the hospital. Leukocytosis was present in 54 patients. All patients undergone sonographic evaluation. Swollen/enlarged pancreas revealed in nineteen patients. Cholelithiasis detected eight patients.

Sludge/Microlithiasis detected in gallbladder in 05 patients. Choledocholithiasis was not detected but dilated common bile duct was seen in 04 patients. Endoscopic examination was done in 74 admitted patients. Only 08 patients found positive findings. Only 02 patients were expired due to multiple organ dysfunction syndrome (MODS). In this study gallstone was associated with 17 patients. Hypertriglyceridemia was found 04 cases, biliary ascariasis found in 02 patients \& alcoholism was found 01 cases. No underlying cause was found in 81 patients.

Table-I: Showing demographic and clinical findings of Acute pancreatitis $(n=105)$.

\begin{tabular}{|c|c|c|c|}
\hline Variables & & Frequency & Percent \\
\hline \multicolumn{4}{|l|}{ Age group } \\
\hline & $\leq 50$ & 69 & 65.7 \\
\hline & $>50$ & 36 & 34.3 \\
\hline & Mean \pm SD & $42.76 \pm 15.88$ & \\
\hline & $\mathrm{P}$ value & 0.001 & \\
\hline \multicolumn{4}{|l|}{ Sex } \\
\hline & Female & 40 & 38.1 \\
\hline & Male & 65 & 61.9 \\
\hline & $P$ value & 0.015 & \\
\hline \multicolumn{4}{|l|}{ Residence } \\
\hline & Rural & 58 & 55.2 \\
\hline & Urban & 47 & 44.8 \\
\hline & $\mathrm{P}$ value & 0.143 & \\
\hline \multicolumn{4}{|l|}{ Occupation } \\
\hline & Service & 12 & 11.4 \\
\hline & Business & 25 & 23.8 \\
\hline & Student & 12 & 11.4 \\
\hline & Housewife & 35 & 33.3 \\
\hline & Unemployed & 5 & 4.8 \\
\hline & Others & 16 & 15.2 \\
\hline \multicolumn{4}{|c|}{ Economical status } \\
\hline & Poor & 4 & 3.8 \\
\hline & $\begin{array}{c}\text { Lower middle } \\
\text { class }\end{array}$ & 55 & 52.4 \\
\hline & $\begin{array}{l}\text { Higher middle } \\
\text { class }\end{array}$ & 34 & 32.4 \\
\hline & Rich & 12 & 11.4 \\
\hline \multirow[t]{10}{*}{$\begin{array}{c}\text { Clinical } \\
\text { presentation }\end{array}$} & $\begin{array}{l}\text { Abdominal } \\
\text { Pain }\end{array}$ & 105 & 100 \\
\hline & Vomiting & 81 & 77 \\
\hline & Fever & 63 & 60 \\
\hline & $\begin{array}{l}\text { Abdominal } \\
\text { tenderness }\end{array}$ & 28 & 26.7 \\
\hline & Jaundice & 4 & 3.8 \\
\hline & Ascites & 4 & 3.8 \\
\hline & DM & 34 & 32.4 \\
\hline & HTN & 30 & 28.6 \\
\hline & Smoking & 29 & 27.6 \\
\hline & Alcohol & 1 & \\
\hline
\end{tabular}


Table-II: Endoscopic finding of the patient

\begin{tabular}{ll}
\hline Biliary ascariasis & 02 \\
Duodenal ulcer & 02 \\
Gastric ulcer & 02 \\
Gastritis & 02 \\
\hline Table-III: Etiology of the patient & \\
\hline Gall stone/sludge & 17 \\
Hypertriglyceridemia & 04 \\
Biliary ascariasis & 02 \\
Alcohol & 01 \\
No cause & 81 \\
\hline
\end{tabular}

\section{Discussion:}

This study was conducted to find out the etiological pattern, presentation \& demographic of sufferers of acute pancreatitis in Bangladesh. All consecutive patients of acute pancreatitis visited in hospital were included in this study. Out of 105 number of patients male were more, similar observation has also been reported by Ahmed et $\mathrm{al}^{7}$. This may be due to male predominance in our OPD \& female attend hospital in more severe stage of disease. Mean age was found $42.76 \pm 15.88$ yrs (Table-I). More than $47 \%$ patient was below 40 years of age. One study of our country peak incidence was found in the fourth decade. ${ }^{7}$ in alcoholic pancreatitis peak incidence is in the fifth decade in western countries. Whereas pancreatitis associated with gallstones $\&$ other causes peak in the 7 th decade. In our country the lower age incidence may be due to lower life expectancy of Bangladeshi people ${ }^{7}$.

Upper abdominal pain (100\%) radiates to the back \& nausea, vomiting $(77 \%)$ were the most common clinical presentation (Table-I), also reported by a study ${ }^{7}$. Fever was present in $63 \%$ patient which was due to inflammatory process \& some cases due to viral infection(in younger age group). Abdominal tenderness was the most common sign in our study which was also reported in another Bangladeshi study ${ }^{8}$. Ascites is a well-known complication of acute pancreatitis. Ascites was found in severe pancreatitis $18 \%$ to $60 \%{ }^{9,10}$. Pleural effusion was found in $2.8 \%$ cases, which was low in incidence than that of others study ${ }^{11,12}$. We tried to find out the underlying cause of acute pancreatitis. In the present study gall stone was found $16.19 \%$ cases (Table-III). One study in Bangladesh shows gall stone causes $18 \%$ acute pancreatitis ${ }^{7}$. More than two third cases were idiopathic. Extensive investigation is needed to determine the cause. In many studies show that alcohol is the leading cause of acute pancreatitis, but socio-cultural \& religious factor discourage alcohol consumption in our society.

Hypertriglyceridemia was responsible in four cases in our study which was consistent with others ${ }^{7,8}$. Triglyceride level more than $1000 \mathrm{mg} / \mathrm{dl}$ increases the risk of pancreatitis. All patient of this study underwent ultrasonographic investigation. In sixty nine $(65.71 \%)$ patients pancreas appeared to be normal which may be due to poor visualization of the organ. CT scan was done in 23 (21.9\%) patients who had severe acute pancreatitis having normal sonographic findings. In CT, we found seven additional pancreatic findings. Upper GIT Endoscopy was done in 15 patient of them biliary ascariasis was found in 2 cases.

The overall mortality rate was $1.9 \%$. Mortality of severe acute pancreatitis was higher. Death was mostly due to multi organ dysfunction syndrome (MODS) in elderly patient. However, Keya et al showed higher mortality $13.6 \%{ }^{11,12,13}$. For these type of patient intensive care unit (ICU) is necessary in tertiary care hospital. But ICU bed is inadequate in regional tertiary care centre.

\section{Conclusion:}

Acute pancreatitis is a condition associated with high morbidity and mortality. Ascariasis also causes acute pancreatitis in endemic area. Patients usually respond conservative treatment but endoscopic treatment is effective in few cases. Surgery is rarely required. Further study with large sample size; multicenter, prospective randomized controlled study is needed to determine the underlying etiology \& prognostic criteria in our population.

\section{Conflict of Interest: None.}

\section{Acknowledgement:}

I would like to thanks all doctors \& nursing staffs of gastroenterology department of SSMC and North East Medical College, Sylhet, who participated \& making this study possible.

\section{References:}

1. Omar E EL, McLean MH. Gastroenterology. Raltson SH, Penman ID, Stachan MWJ, Hobson RP. Davidson's Principles and Practice of Medicine. 23th edition. Elsevier. 2018; 837-39.

2. Conwell DL, Banks PA. Acute pancreatitis. Greenberger NJ, Blumberg RS. Current diagnosis \& treatment Gastroenterology, Hepatology\& Endoscopy. 3rd edition. McGraw-Hill Education. 2016; 335-42.

3. Tenner S, Steinberg WM. Acute Pancreatitis. Feldman M, Friedman LS, Brandt LJ. Sleisenger and fordtran's gastrointestinal and liver disease: pathophysiology/ diagnosis/management. 9th ed. Philadelphia: Elsevier; 2010; 959-82.

https://doi.org/10.1016/B978-1-4160-6189-2.00058-5

4. Norton J, Berger G, Philip P. Acute and Chronic pancreatitis. Harrison's Principles of Internal Medicine. Newyork McGraw Hill. 19th edition. 2015; 2097-2114.

5. Edward W. Campion M. Acute Pancreatitis, Review article. Forsmark CE, Vege SS, Wilcox CM. N Eng1 J Med. 2016; 375:1972-81. 
https://doi.org/10.1056/NEJMra1505202

PMid:27959604

6. Tenner S, Baillie J, DeWitt J, Vege SS. American College of Gastroenterology Guideline: Management of Acute Pancreatitis. Am J Gastroenterol. 2013; 108(9):1400-15; 1416.

7. Ahmed KU, Ahad MA, Alim MA, Ekram ARMS. Clinical profile of acute pancreatitis in a teaching hospital. Bang Med J Khulna. 2016; 49:7-12.

https://doi.org/10.3329/bmjk.v49i1-2.31818

8. Datta IK, Haque MN, Bhuiyan TM. Clinical profile, degree of severity and underlying factor of acute pancreatitis among a group of Bangladeshi patients. IMC J Med Sci. 2018; 12(1): 06-10.

https://doi.org/10.3329/imcjms.v12i1.35170

9. Durenier T, Laterre PF, Reynaert Ms. Ascites fluid in severe acute pancreatitis: from pathophysiology to therapy. Acta Gastroenterol Belg. 2000; 63: 264-68.

10. Maringhini A, Ciambra M, Patti R, Randazzo MA, Dardononi $\mathrm{G}$, et al. Ascites pleural and pericardial effusion in acute pancreatitis. A prospective study of incidence, natural history and prognostic role. Dig Dis Sci. 1996; 41:848-52.

https://doi.org/10.1007/BF02091521

PMid:8625753

11. Kaya E, Dervisoglu A, Polat C. Evaluation of diagnostic findings and scoring systems in outcome prediction in acute pancreatitis. World J Gastroenterol. 2007; 13(22): 3090-4.

https://doi.org/10.3748/wjg.v13.i22.3090

PMid:17589925 PMCid:PMC4172616

12. Beaux AC, Palmer KR, Carter DC. Factors influencing morbidity and mortality in acute pancreatitis; an analysis of 279 cases. Gut. 1995; 37:121-126.

https://doi.org/10.1136/gut.37.1.121

PMid:7672660 PMCid:PMC1382782

13. Chatzicostas C, Roussomoustakaki M, Vlachonikolis IG, Notas G, Mouzas I, Samonakis D, et al. Comparison of Ranson, APACHE II and APACHE III scoring systems in acute pancreatitis. Pancreas. 2002; 25: 331-335. https://doi.org/10.1097/00006676-200211000-00002

PMid:12409825 